\title{
Screening of Local Rice Varieties Grown in Khyber Pakhtunkhwa; Blending High Amylose Rice Flour Modified Functional and Pasting Profile of Low Amylose Rice Flour
}

\author{
Muhammad Ilyas Khan*, Ihsan Mabood Qazi and Mohammad Ayub
}

Department of Food Science and Technology, Faculty of Nutrition Sciences, The University of Agriculture Peshawar, Khyber Pakhtunkhwa, Pakistan.

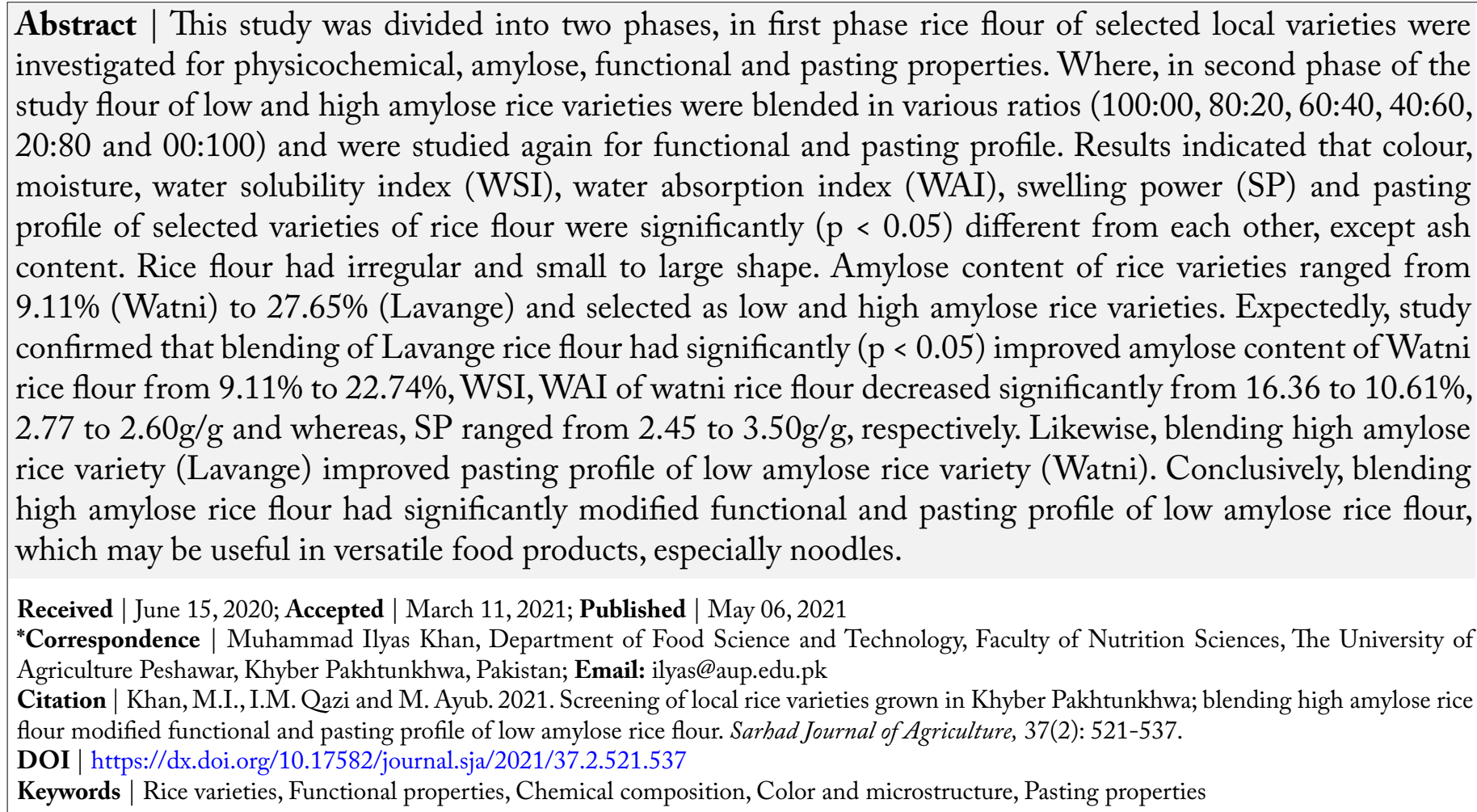

\section{Introduction}

$\mathrm{R}$ ice (Oryza sativa L.) is a food, which is mostly used throughout the world. Generally, more than half of population used rice as staple food. Originally, rice grown is consumed as milled grains. In Asian countries, rice flour is used for the production of many rice products like rice pasta, rice cakes, infant foods, noodles and puddings (Chou et al., 2014). Wheat is also substituted by the rice flour in many products because rice flour is colorless and have low sodium level which exhibit hypoallergenic properties (Zhu et al., 2010; Vongsawasdi et al., 2009).

Generally, rice is consumed as a whole in cooked form and as ingredient in different commodities (Fresco, 2005; Singh et al., 2005; Cai et al., 2011; Hossain et al., 2009). The products in which the rice flour is used as aningredient are bakery products such as cake, cookies and also used in noodles production (Islam et al., 2012; Bhattacharya et al., 1999). Asian food like bakery products, noodles and extruded products are 
being made from rice flour and it is also used as an additives for other ingredients. The physicochemical properties of rice flour play a vital role in the quality of many products (Bhattacharya et al., 1999; Jangchud et al., 2004). These physicochemical properties greatly influenced the eating and cooking qualities of rice. The said properties have also considerable importance on the quality parameters of the end products such as bread and noodles (Juliano, 1985). The type of rice and their origin change the consumer preference (Azabagaoglum et al., 2009). Rice flour may be obtained from the fine milling of white rice or brown rice (Kinsella, 1976). Wheat flour contained high gluten content which causes irritation in the digestive system. Therefore, rice flour is a good substitute for wheat flour and noodle preparation (Yalchin and Basmani, 2008).

Countries like India, Japan, Thailand used rice flour for making noodles, desserts etc. It is also a thickening agent for custard, gravies and sweets (Yalchin and Basmani, 2008; Hu et al., 2009; Thumrongehote et al., 2012). In refrigerated or frozen products rice flour is used as thickening agent because it stops syneresis (Kinsella, 1976; Kaur and Singh, 2006; Siddiq et al., 2009). Noodles were made from the flour of selected rice varieties and were compared for various selected properties (Suraiya et al., 2016). It is difficult to prepare noodles from some varieties grown in Khyber Pakhtunkhwa. This might be due to lack of amylose in these varieties. However, researchers have not investigated these varieties for amylose content, pasting profile, thermal profile, in addition the noodles were studied only for sensory properties, cooking quality and proximate composition.

Therefore, there is a lot of scope to work on Pakistani rice varieties especially on varieties grown in Khyber Pakhtunkhwa for noodle preparation on the basis of their amylose content, pasting profile and thermal properties. Subsequently, making noodles from amylose deficient rice varieties by blending with high amylose rice varieties of the utmost importance to make use of underutilized rice varieties. This will in turn benefits the farmer as well as the noodles producers and will improve living standard of local farmers.

\section{Materials and Methods}

Flour of selected rice varieties namely, Begame,
Lavange, China Begame, Fakhre Malakand, JP5, Basmati 385, Watni, Shamoze Lavange and Swati 2014 were characterized with the aim to exploit the underutilized rice varieties for noodles production. This study was divided into two stages, in first stage rice flour of selected varieties were investigated for physicochemical properties, functional properties and pasting profile. Where, in second stage of the study flour of low and high amylose rice varieties were blended in various ratios (100:00, 80:20, 60:40, 40:60, 20:80 and 00:100) and were again subjected to evaluation for selected quality parameters namely, amylose, water absorption index (WAI), water solubility index (WSI), swelling power (SP) and pasting profile.

\section{Classification of flour of selected rice varieties}

In first experiment flour of selected rice varieties were examined physicochemical properties including colour, scan electronic microscopy (SEM), moisture, ash and amylose content), functional namely, water absorption index (WAI), water solubility index (WSI) and swelling power (SP) and pasting profile such as, peak viscosity (PV), break down (BD), trough viscosity (TV), set back (SB), final viscosity $(\mathrm{FV})$, peak time and pasting temperature.

\section{Colour}

Colour Tech was used to determine the appearance of rice flour of the selected varieties (Qazi et al., 2011). Colour of rice flour samples was examined in term of L* (index of lightness/darkness), a* (index of hue, red/green) and $b^{*}$ (index of yellow/blue). Transparent sample container was fully covered with rice flour samples and was placed in its respective pot and top was placed over it to avoid any external light to enter. Then equipment was run and the specified parameters were recorded automatically.

\section{Scan electronic microscopy}

Scanning electron microscope (SEM) was used for scanning the rice flour samples with beam of $10 \mathrm{KV}$ (Niu et al., 2014). Rice flour samples were dehydrated and was placed on the aluminum stub by mean of double sided tape and were coated with thin layer of gold $(50 \mathrm{~nm})$ and were irradiate with beam of electron at $10 \mathrm{KV}$. The electron reflected back to a sensor for examination of flour particles features in detail and recorded in the form of images with magnification of 1500 to $2000 \mathrm{X}$. 
Determination of moisture (\%)

The percent moisture was determined by using hot air oven (AACC, 2013). Rice flour of $2 \mathrm{~g}$ was placed in petri dish $\left(\mathrm{w}_{1}\right)$ and were placed at $105 \pm 5{ }^{\circ} \mathrm{C}$ in an oven for 4 to 6 hours. After this selected time the oven was turn off and the petri dishes were cooled by placing it in desiccators. Again, weigh the petri dishes $\left(\mathrm{w}_{2}\right)$ and calculate the moisture by using the Equation 1.

Moisture $(\%)=\frac{\text { weight of Initial sample }- \text { weight of sample after drying }}{\text { weight of initial sample }} \times 100$ $\ldots(1)$

\section{Determination of ash (\%)}

Rice flour samples were measured for the ash content by mean of straight ash method (AACC, 2013). Required apparatus used in this experiment were muffle furnace, burner, crucible, weighing balance etc. Cleaned crucible was filled with $2 \mathrm{~g}$ pre-dried flour sample. Collected sample was then ignited and was then transferred to the muffle furnace having $550^{\circ} \mathrm{C}$. The flour color changes to grey white after complete burning (4 to $6 \mathrm{~h}$ ) of organic matters. Once the organic matters are completely oxidized turn off the furnace and remove the sample, place it in desiccators to cool it down. After cooling crucibles weigh it again along with ash and calculate as content according to the following Equation 2.

Ash $(\%)=\frac{\text { weight of sample before ashing }- \text { weight of sample after ashing }}{\text { weight of sample }} \times 100$

\section{Amylose content}

Iodine method was used to measure the amylose content of rice varieties by the method of (Juliano, 1971). Flour sample of $100 \mathrm{mg}$ was placed in beaker and $95 \%$ of Ethyl alcohol solution of $1 \mathrm{ml}$ was also added to each sample. After that $1 \mathrm{M} \mathrm{NaOH}$ solution at a rate of $9 \mathrm{ml}$ was added to each sample. Then the solution was transferred to $100 \mathrm{ml}$ volumetric flask and for at least $10 \mathrm{~min}$ in a water bath. Leave it to cool then add distilled water to make volume up to $100 \mathrm{ml}$. Then solution was thoroughly shook for complete mixing and stored at room temperature. Blank experiment was performed at the same time. Contents of the flask was mixed well by shaking each solution after 23 hours storage. Volumetric flask (100 $\mathrm{ml}$ ) was filled with $5 \mathrm{ml}$ of solution then $70 \mathrm{ml}$ of distilled water and $1 \mathrm{ml}$ of $1 \mathrm{M}$ glacial acetic acid solution and $2 \mathrm{ml}$ of iodine solution (about $10 \mathrm{~g} \mathrm{KI}+$ $1 \mathrm{~g}$ iodine properly mixed in 1 liter of distilled water to prepared $\mathrm{I}_{2}$ solution just 24 hours before use) was added to it and the content of the flask was mixed well and left for $20 \mathrm{~min}$ to form a dark blue color. Absorbance of color was measured at $620 \mathrm{~nm}$ by using spectrophotometer. Starch of known concentration of amylose was used to prepare a standard curve. Absorbance reading was converted to percentage by using standard curve (Figure 1).

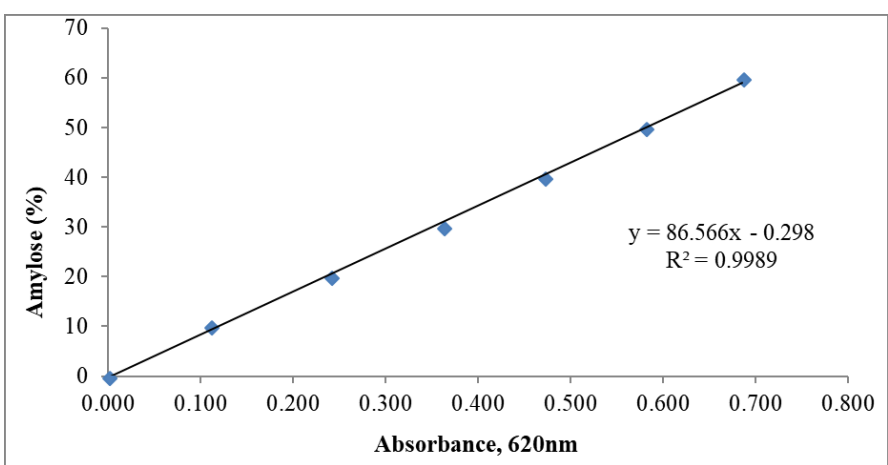

Figure 1: Standard curve of amylose at absorbance of $620 \mathrm{~nm}$.

Water absorption index and water solubility index Both the properties of flour of selected rice varieties are studied by using method of (Thurmrongchote et al., 2012). Put $1 \mathrm{~g}$ of sample in a centrifuge tube having distilled water. Heat the samples at $80^{\circ} \mathrm{C}$ for 30 minutes using a water bath and vibrated to properly mix after each 10 minutes. For 10 minutes the tubes were centrifuged at a speed of $2500 \mathrm{rpm}$. The clean petri dishes were poured with supernatant and placed in an oven at $105^{\circ} \mathrm{C}$ for $10 \mathrm{hrs}$. The petri dishes were weighed again and the WAI and WSI were determined using the below Equations 3 and 4 .

$$
\begin{aligned}
& \text { Water absoprtion index }=\frac{\text { weight of wet sediment }}{\text { weight of dried flour }} \\
& \text { water solubility index }(\%)=\frac{\text { weight of dried supernatant }}{\text { weight of dried flour }} \times 100
\end{aligned}
$$

\section{Swelling power (SP)}

SP of the sample was measured by the method (Schoch, 1964) with certain modification. From selected rice flour $0.2 \mathrm{~g}$ was put in a centrifuge tube in 3 replicates and $10 \mathrm{ml}$ of distilled water was added to each tube. Heat each tube on water bath for 30 minutes and to avoid grit formation shake after each 10 minutes. Centrifuge tube was detached from water bath after 30 minutes and kept at room temperature for cooling. The tubes were then put in a centrifuge and rotated at a speed of $3000 \mathrm{rpm}$ for 15 minutes. Supernatants was collected after 15 minutes in a clean petri dish and then weighed. The supernatants were heated along with petri dish in an oven for 24 
hours at $105^{\circ} \mathrm{C}$. Swelling power of wheat flour after dehydration was calculated using Equation 5.

Swelling power $=\frac{\text { weight of sediment }}{\text { weight of flour }}$

weight of flour - weight of dried supernatant

\section{Pasting profile}

Pasting properties of the flour of selected rice varieties grown in Khyber Pakhtunkhwa were determined by rapid visco analyzer (RVA) with cline window software by using method of (AACC, 2013). Initially the moisture of all the flour was adjusted to $14 \%$ then $3 \mathrm{~g}$ of sample of flour was taken in RVA canister and enough distilled water was poured to attain total weight of $28 \mathrm{~g}$. The material was dispersed vigorously to make slurry by jogging the plastic paddle having blades. Canister along with paddle was then placed in the RVA instrument. Slurry of rice flour samples were stirred by the paddle in the canister at speed of 960 $\mathrm{rpm}$ for $10 \mathrm{sec}$. then at $160 \mathrm{rpm}$ for rest of the test. Five stages for standard temperature profile are; (1) holding the samples for one minutes at a temperature of $50^{\circ} \mathrm{C},(2)$ raising temperature to $95^{\circ} \mathrm{C}$, over period of 3.42 minutes, (3) continue to heat the slurry for 2 minutes at $95^{\circ} \mathrm{C}$, (4) then cooling down the slurry to $50^{\circ} \mathrm{C}$ within 3.48 minutes and (5) finally holding the slurry for next 2 minutes at the temperature of $50^{\circ} \mathrm{C}$. At every four seconds temperature and viscosity values were observed. By using rapid visco unit pasting profile such as peak viscosity (Obtained at stage 2), through (at step 3), final viscosity (at end of the run), pasting temperature (temperature at which starch granule swell and gelatinized), peak time (time to obtained peak viscosity), breakdown (difference between peak viscosity and trough), and setback (difference between final viscosity and through) were recorded.

\section{Results and Discussion}

The selected rice varieties namely, Begame, Lavange, China Begame, Fakhre Malakand, JP5, Basmati 385, Watni, Shamoze Lavange and Swati 2014 were characterized with the aim to exploit the underutilized rice varieties for noodles production. This doctoral study was divided into three stages, in first stage rice flour of selected varieties were investigated for physicochemical properties (colour, moisture, ash and amylose content), functional (water absorption index, water solubility index and swelling power) and pasting profile (peak viscosity, break down, trough viscosity, set back, final viscosity, peak time and pasting temperature). Where, in second stage of the study flour low and high amylose rice varieties were blended in various ratios (100:00, 80:20, 60:40, 40:60, 20:80 and 00:100) and were subjected to evaluation for selected quality parameters namely, amylose, water absorption index (WAI), water solubility index (WSI), swelling power (SP) and respective pasting profile.

\section{Physico-chemical analysis of rice varieties flour}

Color: Color is the elementary quality attributes which provide information about product age and quality (Mares and Cambell, 2001). The color parameters L*(index of lightness/darkness), a* (index of hue, red/green) and $b^{*}$ (index of yellow/blue) of the rice flour of selected varieties are shown in (Table 1). Statistical analysis showed significant $(P<0.05)$ difference in terms of $\mathrm{L}^{*}, \mathrm{a}^{*}$ and $\mathrm{b}^{*}$ values between flour samples of selected rice varieties grown in Khyber Pakhtunkhwa. The $L^{*}$ value of rice flour of selected varieties were in the range of 70.34 (Fakhre Malakand) to 78.36 (China Begame). The results obtained are in agreement with the study of Liu and Shen (2007) and Qazi et al. (2011, 2014) who reported that rice flour have high translucent values are considered excellent. They further recommended that $\mathrm{L}^{*}$ above 70 is suitable for noodle production.

Table 1: Color $\left(L^{*}, a^{*}, b^{*}\right)$ of the flour of selected rice varieties grown in Khyber Pakhtunkhwa.

$\begin{array}{llll}\text { Varieties } & \mathbf{L}^{*} & \mathbf{a}^{*} & \mathbf{b}^{*} \\ \text { Begame } & 76.77 \pm 0.02 \mathrm{c} & 2.97 \pm 0.01 \mathrm{~d} & 11.13 \pm 0.02 \mathrm{c} \\ \text { Lavange } & 75.62 \pm 0.03 \mathrm{~d} & 3.05 \pm 0.04 \mathrm{c} & 9.82 \pm 0.03 \mathrm{fg} \\ \text { China Begame } & 78.36 \pm 0.02 \mathrm{a} & 2.82 \pm 0.03 \mathrm{e} & 9.84 \pm 0.04 \mathrm{f} \\ \text { Fakhre Malakand } & 70.34 \pm 0.03 \mathrm{~h} & 3.55 \pm 0.02 \mathrm{a} & 10.96 \pm 0.02 \mathrm{~d} \\ \text { JP5 } & 73.81 \pm 0.02 \mathrm{f} & 2.33 \pm 0.03 \mathrm{~g} & 10.52 \pm 0.02 \mathrm{e} \\ \text { Basmati 385 } & 74.83 \pm 0.04 \mathrm{e} & 2.93 \pm 0.04 \mathrm{~d} & 11.55 \pm 0.01 \mathrm{~b} \\ \text { Watni } & 73.45 \pm 0.05 \mathrm{~g} & 2.75 \pm 0.02 \mathrm{f} & 9.80 \pm 0.03 \mathrm{~g} \\ \text { Shamoze Lavange } & 78.33 \pm 0.03 \mathrm{a} & 3.18 \pm 0.02 \mathrm{~b} & 10.94 \pm 0.04 \mathrm{~d} \\ \text { Swati 2014 } & 76.96 \pm 0.02 \mathrm{~b} & 3.08 \pm 0.02 \mathrm{c} & 11.67 \pm 0.02 \mathrm{a}\end{array}$

Where, $a^{*}$ value for selected rice varieties were in the range of 2.75 (Watni) to 3.18 (Shamoze Lavange). Likewise, maximum $b^{*}$ value of (11.67) was recorded for flour of Swati 2014 rice variety, while minimum $b^{*}$ value of (9.80) was recorded for flour of Watni rice variety. Values of $\mathrm{a}^{*}$ and $\mathrm{b}^{*}$ indicated that flour samples of all selected rice varieties had slightly towards green and yellow shade, respectively, which 
is very well reflected from the $\mathrm{L}^{*}$ values of the flour samples. However, these values are still well above the acceptable level of high quality flour and subsequently various products especially, noodles production (Kasemsuwan et al., 1998; Liu and Shen, 2007; Qazi et al., 2011, 2014). Variation in xanthophyll and ash content significantly effected color of rice flour of different varieties (Kaur et al., 2013). Similarly, inherent pigments of respective botanical sources, flour composition such as protein and carbohydrate involved in non-enzymatic browning are major contributors to rice flour colour and its products (Kaushal et al., 2012; Pedreschi et al., 2006). Similarly, Kaur et al. (2013) reported that the yellowness is due to the presence of xanthophyll content of the flour. Low value of chroma and lightness of high values are desired for good quality rice flour (Liu and Shen, 2007; Qazi et al., 2011). Hence, concluded that flour of all rice varieties had desirable lightness and of good hue for noodles production.

SEM: Scan electronic microscopy (SEM) was used for detail examination of shape and surface features of the flour particles of Begame, Lavange, China Begame, Fakhre Malakand, JP5, Basmati 385, Watni, ShamozeLavange and Swati 2014 rice varieties grown in Khyber Pakhtunkhwa (Figure 2). Image presented in Figure 2a revealed that Begame rice flour had irregular small and large particles. Where, Lavange rice flour had mostly composed of large particles (Figure 2b). However, small adhered bodies were also observed with flour particles of both the varieties, which might be protein molecules (Gutierrer et al., 2002). On the other hand, images presented in Figure $2 c$ regarding flour particles of China Begame rice variety had mostly composed of large irregular particles having very few small particles in between these large one with no visible signs of adhered bodies. While, Fakhre Malaknad rice variety had mixture of small, medium and large irregular shaped particles with no signs of adhered bodies (Figure 2d). In contrast, JP5 flour particles are mostly conglomerate, means flour particles joined together and appeared like a small ball (Figure 2e). At last flour of Watni, Shmaoze Lavange and Swati 2014 are composed of irregular small, medium and large particles. However, flour particles of Watni are more compact than rest of the two rice varieties flour particles (Figure 2, h and i). But flour of Swati 2014 had mostly composed of large particles having expected adhered protein bodies (Gutierrer et al., 2002).
The size of starch granules influenced the various properties namely, functional and pasting profile and subsequently overall quality of the noodles (Naifu et al., 2016). Flour with large particles normally required more processing time for noodles production (Chen et al., 2003). Likewise, protein in the rice flour wrapped around to starch granules restricted the swelling power of the starch granules and act as a physical, even present in space between the starch granules and also on the surface of the starch granules after cooking (Ye et al., 2018). Likewise, particle size of the starch granules also affected the texture of the noodles. Small particle sized starch produces noodles with high tensile strength than that of large particle sized starch Nura et al. (2011). Similarly, Yoenyong Buddhagal and Noonherm (2002) and Hatcher et al. (2002) reported that the texture of noodles could be enhanced by using fine flour, because the small particle gelatinized quickly as compared to large particle sized starch. Additionally, heat and water can easily penetrate inside the small particle the high paste viscosity of the fine particle flour showed a high proportion of gelatinized starch which is the binding agent and improve the texture of noodles (Fu, 2008; Nura et al., 2011). Conclusively it is stated that all the studied rice varieties had mixture of small, medium and large irregular elongated particles which not only greatly influence functional and pasting properties of flour but will also produce noodles of different texture and quality acceptability.

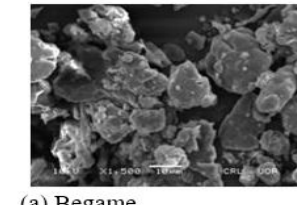

(a) Begame

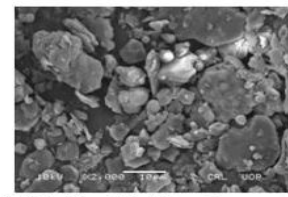

(d) Fakhre Malakand

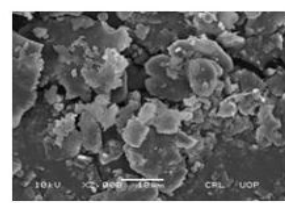

(g) Watni

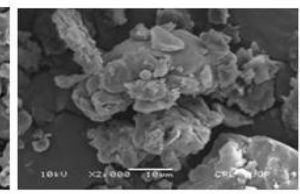

(b) Lovange

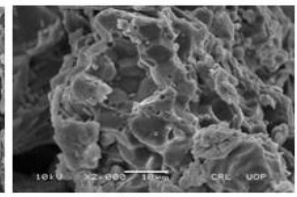

(e) JP5

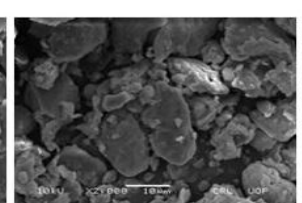

(h) ShamozeLovange

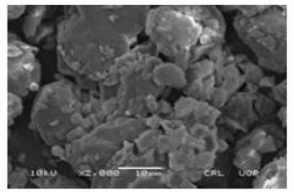

(c) China begame

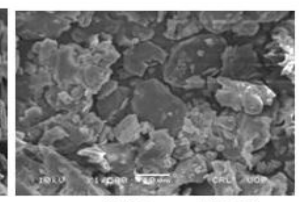

(f) Basmati 385

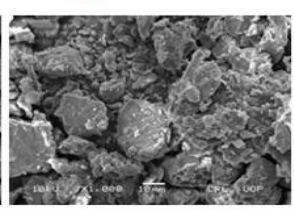

(i) Swati 2014 .
Figure 2: SEM Image of flour particles of (a) Begame, (b) Lavange, (c) China Begame, (d) FakbreMalakand, (e) JP5, Basmati 385, (g) Watani, (h) ShamozeLavange and (i) Swati 2014 rice varieties grown in Khyber Pakhtunkbwa, Pakistan.

Moisture: Moisture content is an important quality parameter that affects the storage life of the rice flour 
(Rosniyana et al., 2013). Percent moisture of the flour of selected rice verities are given in (Table 2). Statistically, there was significant $(\mathrm{P}<0.05)$ difference between the moisture content of all the selected rice varieties flour. The data from the table disclosed that flour Begame variety had high moisture (11.33\%), while flour of Watni had low moisture (8.30\%) among the tested varieties. The results are in accordance with the findings of Islam et al. (2011), Nura et al. (2011) and Thumrongchote et al. (2012), who concluded that the moisture of the rice flour ranged from 5 to $9.61 \%$. The data also revealed that flour of all the selected rice varieties were in the safe limit (less than 12\%) for storage as previously reported by Son (2007). Similarly, Omeire et al. (2014) and Nnam (2002) reported that for longer and safe storage of flour, moisture content below $12 \%$ is necessary. Flour with more than $12 \%$ moisture content is liable to insect infestation, microbial growth, flavor change and enzyme activities (Hoseney, 1994; Saeid et al., 2015). Likewise, Hoseney (1994) also reported high lipolytic and proteolytic enzyme activities in high moisture content flour which decreased protein and fat content in the flour. On the other hand, finding of the Kassegn (2018) and Adom et al. (2005) revealed that low moisture in flour reduced the rate of biochemical reactions and mold growth which in turn improved the shelf stability of the flour. Moisture content of the rice flour is affected by variety, climate and storage condition, milling, processing and milling temperature (Nishata and Bean, 1982; Masood et al., 2004; Eshun, 2012; Saeid et al., 2015; David et al., 2015; Suriya et al., 2016). Thus, concluded that rice flour of all selected variety were very well within the safe limit.

Table 2: Moisture (\%), ash (\%) and amylose (\%) contents of flour of rice varieties grown in Khbyber Pakhtunkhwa.

$\begin{array}{llll}\text { Varieties } & \text { Moisture (\%) } & \text { Ash (\%) } & \text { Amylose (\%) } \\ \text { Begame } & 11.33 \pm 0.57 \mathrm{a} & 0.95 \pm 0.02 \mathrm{a} & 26.20 \pm 0.08 \mathrm{~b} \\ \text { Lavange } & 9.70 \pm 0.15 \mathrm{~d} & 0.98 \pm 0.01 \mathrm{a} & 27.65 \pm 0.09 \mathrm{a} \\ \text { China Begame } & 10.53 \pm 0.93 \mathrm{bc} & 0.95 \pm 0.02 \mathrm{a} & 24.57 \pm 0.33 \mathrm{e} \\ \text { Fakhre Malakand } & 10.70 \pm 0.10 \mathrm{abc} & 0.94 \pm 0.04 \mathrm{a} & 26.30 \pm 0.1 \mathrm{~b} \\ \text { JP5 } & 10.66 \pm 0.12 \mathrm{bc} & 0.95 \pm 0.03 \mathrm{a} & 26.27 \pm 0.06 \mathrm{~b} \\ \text { Basmati 385 } & 10.80 \pm 0.20 \mathrm{ab} & 0.95 \pm 0.01 \mathrm{a} & 25.71 \pm 0.10 \mathrm{c} \\ \text { Watni } & 8.30 \pm 0.09 \mathrm{e} & 0.95 \pm 0.01 \mathrm{a} & 9.11 \pm 0.10 \mathrm{f} \\ \text { Shamoze Lavange } & 10.10 \pm 0.19 \mathrm{~cd} & 0.97 \pm 0.03 \mathrm{a} & 26.30 \pm 0.11 \mathrm{~b} \\ \text { Swati 2014 } & 10.13 \pm 0.14 \mathrm{~cd} & 0.98 \pm 0.00 \mathrm{a} & 24.99 \pm 0.48 \mathrm{~d}\end{array}$

June 2021 | Volume 37 | Issue 2 | Page 526
Percent ash: Ash is the total mineral content present in the flour (Saeid et al., 2015). Ash of the flour of rice varieties studied given in (Table 2 ). Statistical analysis divulged non-significant $(\mathrm{P}<0.05)$ difference in the ash content of selected rice varieties. Data exposed that the range of the ash content of the selected varieties were $0.94-0.98 \%$. The result is in closed resemblance with the findings of Wadchararat et al. (2006), Islam et al. (2011) and Thamrongchote et al. (2012) who reported the range of ash content in rice flour between 0.40 to $1.5 \%$. This variation might be due to differences in varieties, milling procedure, agronomic practices, origin, climate and soil conditions (Han et al., 2011; Bilgicli, 2013; Saeid et al., 2015; Kassegn, 2018). High ash content flour produces product with darker color which had negative impact on the consumer preference (Aravind et al., 2012). Similarly, Heinio et al. (2016) reported that flour having high ash produced pasta with darker color and less glossy appearance. There is no such cutoff regarding ash content of flour for good quality noodles, however, Han et al. (2011) and Gulia et al. (2014) reported that flour with ash content less than $1 \%$ produced noodles with high acceptability rate, especially in terms of colour. On the basis of above discussion this is concluded that flour of all the selected rice varieties grown in Khyber Pakhtunkhwa are very well suitable for noodles production.

Amylose: Amylose is one of the most important quality components of rice flour and subsequently for noodles production (Fu, 2008; Qazi et al., 2011). According to statistical data there is significant $(\mathrm{P}<$ 0.05) difference in the amylose content between the flour of rice varieties (Table 2). Data presented here disclosed that flour of Lavange variety had maximum amylose content (27.65\%), while low amylose was observed in the flour of Watni variety (9.11\%). The variation in amylose content between the rice varieties may be due to growing area, variation in fertilizer, growing conditions, genetic makeup and method of amylose determination (Tan et al., 2009; Saied et al., 2015). Similarly, gel strength of the starch also depends on the amylose content of the flour/ starch, higher the amylose high will be gel strength (Ishguro et al., 2000). Likewise, amylose had also significant effect on the swelling power and solubility of starch (Liu and Shen, 2007). Texture of noodle is highly affected by the amylose content of rice flour (Nura et al., 2011; Fari et al., 2011; Qazi et al., 2011). Additionally, noodle hardness and stickiness also 
depending on amylose content (Fari et al., 2011). Rice flour having high amylose content considered best for production of rice noodles ( $\mathrm{Li}$ and $\mathrm{Luh}$, 1980). Therefore, rice noodles can be made from flour or starch having high amylose content which give high textural and cooking qualities. The intermediate amylose flour produced noodles with soft texture, while low amylose content flour or waxy starch is not suitable for noodles production (Suriya et al., 2016; Sookdang, 1998). Amylose had major contribution in pasting properties of starch (Singh et al.,2006). Flour/ starch with high amylose level bind more water during gelatinization resulted in opaque gel, hard and nonsticky textured noodles (Murphy, 2000; Sandhu and Kaur, 2010). Conclusively, all varieties are categorized in high amylose content, except Watni, which is classified as low amylose rice variety. Two varieties were selected namely, Lvange and Watni as high and low amylose rice variety respectively for blending and subsequently for noodles preparation.

\section{Functional properties of flour of rice varieties}

Water absorption index: Water absorption index (WAI) of the rice flour presented in (Table 3). Statistical analysis showed significant $(\mathrm{P}<0.05)$ difference in WAI of flour of rice varieties studied. This was observed from the data that among all the varieties lavange had low $(2.33 \mathrm{~g} / \mathrm{g})$ WAI, while swati has high $(3.10 \mathrm{~g} / \mathrm{g})$. These results are in accordance with the outcomes of Thumrongehote et al. (2012) and Heo et al. (2013), who observed that WAI of rice flour ranged between 3.3 to $8 \mathrm{~g} / \mathrm{g}$. The difference in WAI of rice flour may be due to level of damage starch, milling method and temperature as previously reported by Heo et al. (2013). Additionally Nura et al. (2011), Thumrongehote et al. (2012) and Chandra and Shamsher (2013) reported that amylose, protein, carbohydrate and fiber content had also significantly affected WAI of rice flour. The concentration of starch and fiber in flour increased the water absorption index (Chandra and Samsher, 2013). Furthermore, particle size of flour had notably affected the WAI of the rice flour (Nura et al., 2011; Thumrongehote et al., 2012). Chiang and Yeh (2002) found a direct relationship $(\mathrm{R} 2=0.93)$ between water absorption index and damaged starch level. Flour with good water absorbing ability produced noodles with softer texture and high acceptability Qazi et al. (2014). Thus, conclude that rice flour had good WAI that suited noodles production requirements.
Table 3: Functional properties of flour of selected rice varieties grown in Khyber Pakbtunkbwa.

$\begin{array}{llll}\text { Varieties } & \text { WAI }(\mathbf{g} / \mathbf{g}) & \text { WSI }(\%) & \mathbf{S P}(\mathbf{g} / \mathbf{g}) \\ \text { Begame } & 2.59 \pm 0.04 \mathrm{c} & 7.09 \pm 0.08 \mathrm{~h} & 2.57 \pm 0.03 \mathrm{c} \\ \text { Lavange } & 2.33 \pm 0.11 \mathrm{bc} & 9.24 \pm 0.22 \mathrm{f} & 2.61 \pm 0.11 \mathrm{bc} \\ \text { China Begame } & 2.59 \pm 0.04 \mathrm{c} & 16.95 \pm 0.14 \mathrm{a} & 2.55 \pm 0.04 \mathrm{c} \\ \text { Fakhre Malakand } & 2.62 \pm 0.35 \mathrm{c} & 8.12 \pm 0.10 \mathrm{~g} & 2.60 \pm 0.35 \mathrm{bc} \\ \text { JP5 } & 2.96 \pm 0.32 \mathrm{ab} & 12.64 \pm 0.22 \mathrm{~d} & 2.94 \pm 0.32 \mathrm{ab} \\ \text { Basmati385 } & 2.79 \pm 0.19 \mathrm{abc} & 10.16 \pm 0.04 \mathrm{e} & 2.76 \pm 0.18 \mathrm{abc} \\ \text { Watni } & 2.57 \pm 0.07 \mathrm{c} & 16.33 \pm 0.30 \mathrm{~b} & 2.52 \pm 0.08 \mathrm{c} \\ \text { Shamoze Lavange } & 2.73 \pm 0.29 \mathrm{bc} & 6.32 \pm 0.39 \mathrm{i} & 2.71 \pm 0.30 \mathrm{abc} \\ \text { Swati 2014 } & 3.10 \pm 0.06 \mathrm{a} & 14.88 \pm 0.06 \mathrm{c} & 3.05 \pm 0.07 \mathrm{a}\end{array}$

\section{Water solubility index}

Table 3 present water solubility index (WSI) of the flour of selected rice varieties grown in Khyber Pakhtunkhwa. Statistically analysis indicated that WSI of flour selected rice varieties were significant $(\mathrm{P}<0.05)$ different from each other. Data further revealed that WSI of the flour of selected rice varieties ranged between $6.32 \%$ (Shamoze Lavange) to $16.95 \%$ (China Begame). Results pertained here are in close resemblance with the findings of Wadchararat et al. (2006), Thumrongchote et al. (2012) and Heo et al. (2013) who reported that WSI of rice flour ranged between 6 to $7.94 \%$. Water solubility index of rice flour depend on amylose and temperature of the cooking water (Wadchararat et al., 2006). However, temperature had direct relationship with solubility, while amylose had contrary relationship to solubility index of the rice flour (Wadchararat et al., 2006). Similarly, Wadchararat et al. (2006) and Thumrongchote et al. (2012) reported that protein and starch lipid complex are also important factors affecting the WSI of the rice flour. Both protein and lipid form coating on the starch granule surface and made it difficult for water to reach the starch granules which in turn decreasing the WSI of the starch granules (Ye et al., 2018). Moreover, level of damage starch and milling procedure also affected the water solubility index of rice starch and had direct relation (Heo et al.,2013). Furthermore, amylopectin molecule has higher susceptibility to degradation through sheering as compared to amylose, thus an increase in the WSI may be due to the easy percolation of the amylose or small size amylopectin molecule from the damage starch (Okusu et al., 2010; Dhital et al., 2011). There is variation in WSI of flour of selected rice variety that may affect noodles quality. 
Swelling power

Swelling power (SP) is the capacity of starch granules to grasp water, which is the function of amylopectin of the starch (Yuree et al., 2015). Swelling power of rice flour of selected varieties grown in Khyber Pakhtunkhwa given in (Table 3). The data unveiled significant $(\mathrm{P}<0.05)$ differences in $\mathrm{SP}$ of the selected rice varieties flour. Data also disclosed that maximum SP $(3.50 \mathrm{~g} / \mathrm{g})$ was recorded in flour of Swati variety, while minimum SP $(2.52 \mathrm{~g} / \mathrm{g})$ was observed in flour of Watni rice variety. These results are in accordance with the outcomes of Fari et al. (2011), Thumrongchote et al. (2012) and Wadchararat et al. (2006), who concluded that the SP for different rice varieties flour was in the range of 6.5 to $16.23 \mathrm{~g} / \mathrm{g}$. Protein and amylose played important role in swelling power of the rice flour. Protein inhabited granule swelling due to the presence of disulphide bond as reported by Fari et al. (2011) and Wadchararat et al. (2006). Similarly, starch and protein bound with lipids and created amylose lipid complex that affected the SP of rice flour. Several factors like starch type, temperature and protein content of the starch granules played vital role in the swelling power of the starch granules (Suraiya et al., 2016). Similarly, $\mathrm{SP}$ is the water retention capability of flour which is mainly due to the amylopectin (Tester and Morrison, 1990) while, the amylose function is to inhibit the swelling (Techawipharat et al., 2008). Likewise, Wang and Copeland (2012a, 2012c) reported that the swelling power and water binding capacity of the starch granules is due to the unbroken structure of amylopectin part of the granule. Correspondingly, the degradation of starch granule also decreased the swelling power of starch (Guler et al., 2002; Yoenyongbuddhagal and Noomhorm, 2002). In the same way, amylopectin and amylose content and there configuration significantly affected the swelling behavior of the starch granules (Tester and Morrison, 1990). In conclusion, flour of rice varieties is suitable for noodles preparation on basis of SP.

\section{Pasting proflle of rice varieties flour}

Pasting properties are vital parameter for the quality of noodles and has a reliable interpreter for the noodles quality (Offia-Olua, 2014). The pasting profile include Peak viscosity (PV), trough viscosity (TV), break down (BD), final viscosity (FV), setback (SB), peak time (PTi), pasting temperature $(\mathrm{PT})$ of the rice flour of selected varieties grown in Khyber Pakhtunkhwa are given in (Table 4). Data regarding statistical analysis disclosed that pasting profile of all the selected rice varieties flour are significantly $(\mathrm{P}<$ 0.05) different from each other.

High PV is the ability of starch to enlarge freely before physical break and to resist stress and high heating condition (Fari et al., 2011). Peak viscosity of the rice flour of selected varieties was ranged between 542 to 2959.7cP. The rice flour having low amylose starch will have high PV value because of low amorphous region and high degree of crystalline region of the starch granules (Tukomane et al., 2007). Similarly, when majority of the starch granules swells the PV occurred at this stage (Tsai et al., 1997). Breakdown viscosity is the potency of paste during product development (Adebowale et al., 2005). Flour having high breakdown viscosity has the ability to withstand high stress and high heating condition during processing (Chinma et al., 2010; Adebowale et al., 2005). Similarly, the breakdown viscosity of the flour of selected rice varieties was between 90 to $980 \mathrm{cP}$. Trough viscosity ranged between 414 to $2647 \mathrm{cP}$.

Table 4: Pasting profile (cP) of flour of selected rice varieties grown in Khyber Pakhtunkbwa.

\begin{tabular}{llllllll} 
Varieties & Peakviscosity & $\begin{array}{l}\text { Troughvis- } \\
\text { cosity }\end{array}$ & Breakdown & Finalviscosity & Setback & $\begin{array}{l}\text { Peaktime } \\
(\mathbf{m i n})\end{array}$ & $\begin{array}{l}\text { Pastingtemp. } \\
\left({ }^{\circ} \mathbf{C}\right)\end{array}$ \\
Begame & $1085.3 \pm 4.04 \mathrm{f}$ & $987.67 \pm 6.11 \mathrm{f}$ & $90.33 \pm 6 \mathrm{~h}$ & $1683.7 \pm 10.41 \mathrm{f}$ & $691 \pm 8.19 \mathrm{~g}$ & $7.08 \pm 0.55 \mathrm{ab}$ & $93.41 \pm 0.93 \mathrm{c}$ \\
Lavange & $2474 \pm 4.00 \mathrm{~b}$ & $1967.7 \pm 7.02 \mathrm{~b}$ & $507.67 \pm 4.51 \mathrm{c}$ & $4029 \pm 6 \mathrm{~b}$ & $2055.3 \pm 6.03 \mathrm{e}$ & $6.94 \pm 0.16 \mathrm{ab}$ & $88.78 \pm 0.40 \mathrm{e}$ \\
China Begame & $2959.7 \pm 6.66 \mathrm{a}$ & $2647 \pm 8.19 \mathrm{a}$ & $309.33 \pm 4.51 \mathrm{~d}$ & $5543 \pm 9 \mathrm{a}$ & $2891.3 \pm 8.33 \mathrm{a}$ & $6.30 \pm 0.20 \mathrm{ab}$ & $94.27 \pm 1.10 \mathrm{bc}$ \\
Fakhre Malakand & $1289.7 \pm 5.03 \mathrm{e}$ & $1016 \pm 2.65 \mathrm{e}$ & $277 \pm 6.24 \mathrm{e}$ & $1625.3 \pm 9.50 \mathrm{~g}$ & $612 \pm 10 \mathrm{~h}$ & $7.16 \pm 1.26 \mathrm{a}$ & $94.74 \pm 0.11 \mathrm{~b}$ \\
\hline JP5 & $2209.0 \pm 5.57 \mathrm{c}$ & $1238.3 \pm 7.51 \mathrm{~d}$ & $980.67 \pm 6.66 \mathrm{a}$ & $3854.3 \pm 7.51 \mathrm{~d}$ & $2625.3 \pm 8.62 \mathrm{~b}$ & $6.52 \pm 0.52 \mathrm{ab}$ & $88.33 \pm 0.24 \mathrm{ef}$ \\
\hline Basmati 385 & $884 \pm 5.57 \mathrm{~g}$ & $782.33 \pm 5.86 \mathrm{~g}$ & $115 \pm 10 \mathrm{~g}$ & $3041.3 \pm 10.02 \mathrm{e}$ & $2272.3 \pm 10.02 \mathrm{~d}$ & $6.13 \pm 0.42 \mathrm{~b}$ & $91.64 \pm 0.33 \mathrm{~d}$ \\
Watni & $691.33 \pm 7.09 \mathrm{~h}$ & $616.67 \pm 7.64 \mathrm{~h}$ & $90.33 \pm 6.11 \mathrm{~h}$ & $965.67 \pm 6.03 \mathrm{i}$ & $360 \pm 9.54 \mathrm{i}$ & $6.82 \pm 0.46 \mathrm{ab}$ & $95.78 \pm 0.27 \mathrm{a}$ \\
\hline Shamoze Lavange & $2179.7 \pm 8.33 \mathrm{~d}$ & $1286.7 \pm 9.61 \mathrm{c}$ & $888 \pm 10.54 \mathrm{~b}$ & $3877.7 \pm 8.33 \mathrm{c}$ & $2587 \pm 6 \mathrm{c}$ & $6.47 \pm 0.41 \mathrm{ab}$ & $87.56 \pm 0.59 \mathrm{f}$ \\
\hline Swati2014 & $542.67 \pm 4.51 \mathrm{i}$ & $414.67 \pm 9.29 \mathrm{i}$ & $137.33 \pm 5.69 \mathrm{f}$ & $1417.0 \pm 6.24 \mathrm{~h}$ & $1011.7 \pm 6.51 \mathrm{f}$ & $6.60 \pm 0.57 \mathrm{ab}$ & $94.45 \pm 0.56 \mathrm{~b}$
\end{tabular}

June 2021 | Volume 37 | Issue 2 | Page 528 
Setback viscosity is the indication of gel constancy and degree of retrogradation (Liang and King, 2003; Niba et al., 2001). Retrogradation is the rearrangement of amylose molecules upon cooling of gel (RodriguezSandoval et al., 2008). A double helical structure is formed by amylose molecule due to hydrogen bonding during cooling process (Denardin and Smith, 2009). Similarly, Chinma et al. (2010) stated that the high $\mathrm{SB}$ value is the indication of starch molecule disperse in hot paste and retrograde upon cooling. Final is the capability of starch granules to become gelatinized upon processing (Liang and King, 2003; Niba et al., 2001). The range of $F V$ of the flour of selected rice varieties were between 965 to $5543 \mathrm{cP}$. Peak time and pasting temperature were in the range of 6.13 to 7.16 minutes and 87 to $95^{\circ} \mathrm{C}$, respectively. The above results are also in agreement with the findings of Qazi et al. (2011), who showed similar range for the pasting parameters of rice flour. Both peak time and pasting temperature had significant role in final product, especially noodles (Hormdok and Noomhorm, 2007; Qazi et al., 2011). Hence, concluded that rice flour having amylose had significant role in pasting profile and subsequently in noodle functional and cooking quality.

\section{Functional properties of blends of high and low amylose rice flour}

Amylose content: Amylose content is important parameter for the structure, gel strength and cooking properties of rice flour noodles (Sofi et al., 2020; Fari et al., 2011; Nura et al., 2011; Qazi et al., 2011). Amylose content of various blends of low and high amylose rice flour blends presented in (Table 5). Statistical analysis showed significant $(\mathrm{P}<0.05)$ difference in amylose content of among various blends of the rice flour. The data from the table disclosed that with the increase in level of rice flour of Lavange variety had increased the amylose content of Watni rice flour. The table also clarified that the blend LAHA (20:80) had high (22.74\%) amylose content and will produced high quality noodles than rest of the blends. The amylose to amylopectin ratio also affects the processing, physicochemical properties and functional properties of the starch (Chen et al., 2019; Schirmer et al., 2013; Singh et al., 2006). The integrity of the starch granule is also maintained by amylose content, that significantly decreased solubility and swelling power of the starch (Chen et al., 2019; Tester et al., 2004). Noodles prepared from flour with high amylose content had low cooking loss and improved texture and considered best for noodle production (Sofi et al., 2020; Qazi et al., 2011; Li and Luh, 1980). The intermediate amylose content flour give product with soft texture, low amylose content flour is not suitable for noodles preparation (Suriya et al., 2016; Sookdang, 1998). This is concluded form the above discussion that amylose content significantly increased with the increase of flour of Lovenge in the blends.

\section{Water absorption index}

The capacity of flour to absorb and hold water during paste and dough formation is called WAI and important characteristics in the production of readyto-eat food from cereal grain like noodles (Singh, 2001; Tharise et al., 2014; David et al., 2015). Water absorption index of various blends of low and high amylose rice flour are shown in (Table 5). This is very well clear from the statistical analysis that WAI of flour samples are significantly $(\mathrm{P}<0.05)$ decreased with increasing level of Lavange rice flour in the blend. Flour of both Lavange and Watni rice flour had high and low WAI mean values $2.41 \mathrm{~g} / \mathrm{g}$ and $2.77 \mathrm{~g} / \mathrm{g}$, respectively. However, blended flour of LAHA (80:20) had higher WAI mean value than rest of the blended flour samples. Inadequate water absorption can leads to hard and course feature noodles, while excess water produced sticky and soft textured noodles (Song et al., 2013). Rice flour absorbed much higher amount of water due to fact of small granule size than rest of the cereals and tuber starches (Nura et al., 2011). Generally, water absorption index of rice flour ranged from 1.92 to $8 \mathrm{~g} / \mathrm{g}$ (Thumrongchote et al., 2012; Heo et al., 2013; Chandra and Samsher, 2013). This was observed that adding wheat flour had significantly reduced WAI of rice flour (Ahmad et al., 2015; Singh et al., 2008; Ammar et al., 2009). Likewise, flour with high level of damage starch had high WAI (Penfield and Campbell, 1990; Kasemsuwan et al., 1998). Moreover, WAI of rice flour influence in the presence of protein, carbohydrate, fiber, fat and amylose. With higher percentage of fibers and starch WAI of the flour increased positively (Nura et al., 2011; Chandra and Samsher, 2013). In contrast, the WAI decrease as the level of amylose increase in the flour (Nura et al., 2011; Adeyeye and Aye, 1998). Similarly, the protein starch interaction also decreased the water absorption capacity of the flour (Fari et al., 2011; Song et al., 2013).

\section{Water solubility index}

Statistical analysis showed significant $(\mathrm{P}<0.05)$ difference in the WSI of different blends of low and 
high amylose rice flour (Table 5). With the addition of high amylose rice flour in blends the WSI of the blend decreased from $14.77 \%$ (LAHA 80:20) to $10.61 \%$ (LAHA 20:80). This decrease in WSI has direct relation with amylose of the rice flour (Wadchararat, 2006). The result having close resemblance with the findings of Heo et al. (2013); Thumongchate et al. (2012) and Wadchararat et al. (2006), who reported that WSI of rice flour ranged from 0.6 to $7.94 \%$. In contrast, some researchers showed positive relationship between amylose and WSI of the rice flour, but yet not confirmed (Thumrongchote et al., 2012). Methods of milling and damage starch content also influenced the WSI of rice flour (Heo et al., 2013). Similarly, protein and starch lipid complex also reduced the stability of rice flour (Thumrongchote et al., 2012; Wadchararat et al., 2006). The WSI of the damage starch flour is more than the normal starch granules. Similarly, temperature, flour composition, amylose, protein, fat and fiber had significant role in WSI (Sathe and Salunkhe, 1981; Wadchararat et al., 2006).

\section{Swelling power}

Swelling power is the capacity of starch granule to absorb water under stress condition (Wadchararat et al., 2006). The crystalline structure of the starch granules disappeared, when heated in excess of water, allowing the water molecule to make a link through hydrogen bonding with the hydroxyl group starch molecules causing an increase in swelling of the starch granules (Ye et al., 2018). Statistical analysis showed significant $(\mathrm{P}<0.05)$ difference among different flour blends of low and high amylose rice varieties (Table 5). The table showed a decrease trend in swelling power of the blend. High SP value of $(6.45 \mathrm{~g} / \mathrm{g})$ was obtained by LAHA $(80: 20)$ as compared to LAHA $(00: 100)$ that is $2.54 \mathrm{~g} / \mathrm{g}$. This increase in SP may be due to high amylopectin as previously reported by (Tester and Morresion, 1990; Yuree et al., 2015). The water absorbing capacity and cooking loss of different rice products may be affected by the solubility and swelling power of the starch granules (Hu et al., 2009). The structure of amylopectin affects gelatinization, refrigeration and pasting properties of rice starch and flour (Bhattacharya, 2009; Jane et al., 1999; Lin et al., 2001). Likewise, Vanclepatte et al. (2003) also concluded that flour having high amylopectin will have high water holding capacity because of higher solubility by the weak starch. Protein and fat content of the flour has also negative effect on the swelling power of the starch granules (Parada and Santos, 2016; Svihus et al., 2005). Rice flour had SP in the range of 3.8 to $16.23 \mathrm{~g} / \mathrm{g}$ (Fari et al., 2011; Heo et al., 2013; Thumrongchote et al., 2012; Wadchararat et al., 2006). Swelling power of rice flour is dictated by processing temperature, milling methods, protein, starch granules, amylose and amylopectin concentration (Hormdok and Noomhorm, 2007; Heo et al., 2013).

Table 5: Amylose and functional properties of flour blends of low and high amylose rice varieties grown in Khyber Pakbtunkhwa.

$\begin{array}{lllll}\text { Blends } & \text { Amylose (\%) } & \text { WAI (g/g) } & \text { WSI (\%) } & \text { SP (g/g) } \\ \text { LAHA 100:00 } & 9.11 \pm 0.22 \mathrm{f} & 2.77 \pm 0.43 \mathrm{a} & 16.36 \pm 0.28 \mathrm{a} & 2.45 \pm 0.22 \mathrm{e} \\ \text { LAHA 80:20 } & 12.80 \pm 0.19 \mathrm{e} & 2.75 \pm 0.27 \mathrm{a} & 14.77 \pm 0.21 \mathrm{~b} & 6.45 \pm 0.19 \mathrm{a} \\ \text { LAHA 60:40 } & 16.47 \pm 0.34 \mathrm{~d} & 2.65 \pm 0.45 \mathrm{~b} & 13.57 \pm 0.31 \mathrm{c} & 5.73 \pm 0.34 \mathrm{~b} \\ \text { LAHA 40:60 } & 19.49 \pm 0.29 \mathrm{c} & 2.63 \pm 0.23 \mathrm{~d} & 11.61 \pm 0.31 \mathrm{~d} & 4.46 \pm 0.29 \mathrm{c} \\ \text { LAHA 20:80 } & 22.74 \pm 0.27 \mathrm{~b} & 2.60 \pm 0.28 \mathrm{~d} & 10.61 \pm 0.38 \mathrm{e} & 3.50 \pm 0.27 \mathrm{~d} \\ \text { LAHA 00: } 100 & 27.65 \pm 0.31 \mathrm{a} & 2.41 \pm 0.25 \mathrm{f} & 9.23 \pm 0.37 \mathrm{f} & 2.54 \pm 0.31 \mathrm{e}\end{array}$

Table 6: Pasting profile (cP) of flour blends of low and high amylose rice varieties grown in Khyber Pakhtunkbwa.

$\begin{array}{llllllll}\text { Blends } & \text { Peak viscosity } & \begin{array}{l}\text { Trough vis- } \\ \text { cosity }\end{array} & \text { Break down } & \text { Final viscosity } & \text { Set back } & \begin{array}{l}\text { Peak time } \\ (\mathbf{m i n})\end{array} & \begin{array}{l}\text { Pasting temp. } \\ \left({ }^{\circ} \mathrm{C}\right)\end{array} \\ \text { LAHA 100:00 } & 542.67 \pm 9.12 \mathrm{f} & 414.67 \pm 5.06 \mathrm{f} & 137.33 \pm 5.03 \mathrm{f} & 1417.0 \pm 5.63 \mathrm{f} & 1011.7 \pm 7 \mathrm{f} & 6.60 \pm 0.2 \mathrm{a} & 94.45 \pm 0.1 \mathrm{a} \\ \text { LAHA 80:20 } & 3717.0 \pm 7 \mathrm{c} & 2182.7 \pm 4.04 \mathrm{~d} & 1524.3 \pm 5.03 \mathrm{~d} & 4320.7 \pm 6.65 \mathrm{~d} & 2141.0 \pm 6.11 \mathrm{c} & 6.50 \pm 0.3 \mathrm{a} & 68.53 \pm 0.4 \mathrm{bc} \\ \text { LAHA 60:40 } & 5979.7 \pm 9.07 \mathrm{a} & 2684.7 \pm 4.04 \mathrm{~b} & 3286.0 \pm 5.13 \mathrm{a} & 5520.0 \pm 8.54 \mathrm{~b} & 2833.7 \pm 7.50 \mathrm{~b} & 5.51 \pm 0.1 \mathrm{~b} & 67.67 \pm 0.1 \mathrm{c} \\ \text { LAHA 40:60 } & 5633.0 \pm 8.19 \mathrm{~b} & 3163.7 \pm 5.03 \mathrm{a} & 2467.0 \pm 4.02 \mathrm{~b} & 5158.0 \pm 4.01 \mathrm{c} & 1991.3 \pm 8 \mathrm{~d} & 5.67 \pm 0.1 \mathrm{~b} & 50.23 \pm 0.1 \mathrm{~d} \\ \text { LAHA 20:80 } & 2920.3 \pm 6.66 \mathrm{e} & 1319.7 \pm 6.02 \mathrm{e} & 1592.3 \pm 5.13 \mathrm{c} & 3206.0 \pm 5.56 \mathrm{e} & 1881.0 \pm 6.66 \mathrm{e} & 5.43 \pm 0.3 \mathrm{~b} & 69.43 \pm 0.1 \mathrm{~b} \\ \text { LAHA 00: } 100 & 2959.7 \pm 6.76 \mathrm{~d} & 2647.0 \pm 7.23 \mathrm{c} & 309.33 \pm 4.14 \mathrm{e} & 5543.0 \pm 5.72 \mathrm{a} & 2891.3 \pm 8.32 \mathrm{a} & 6.30 \pm 0.1 \mathrm{a} & 94.27 \pm 0.1 \mathrm{a}\end{array}$


Pasting profile of blends of high and low amylose rice varieties

Table 6 shows pasting profile (peak viscosity, trough viscosity, break down, setback, final viscosity, peak time and pasting temperature) of various blends of low and high amylose rice varieties flour. Statistical analysis clearly indicated that pasting properties of these low amylose rice flour had significantly $(\mathrm{P}<$ 0.05) influenced with the blending of high amylose rice flour. The data disclosed that with the increase in high amylose rice flour in the blend PV increased, with high PV of 5979cP (LAHA60:40). High PV is the ability of starch granule to swell freely before physical breakdown and to resist stress and high heating condition (Fari et al., 2011). Breakdown viscosity is the potency of paste during product development (Adebowale et al., 2005). The BD of the blends increased significantly $(\mathrm{P}<0.05)$ with the addition of high amylose rice flour in the blends. Data revealed that (LAHA 60:40) had higher BD mean value of $3286 \mathrm{cP}$ than rest of blended flour samples. Similar results were found by Qazi et al. (2011), where flour has high breakdown viscosity has the ability to withstand high stress and high heating condition during processing (Chinma et al., 2010; Adebowale et al., 2005). Similarly, TV of the blinds modified positively with the addition of high amylose rice flour. High TV mean value of $(3163.7 \mathrm{cP})$ in blended flour sample was recorded for (LAHA 40:60). The results are in agreement with the finding of the Qazi et al. (2011), who reported that the pasting properties of the rice flour blends with other starch modified and have a positive effect on the properties of the final products.

The setback viscosity of various flour blends of high and low amylose rice varieties significantly $(\mathrm{P}<0.05)$ different from each other and ranged between $1881 \mathrm{cP}$ (LAHA 20:80) to 2833cP (LAHA 60:40). Set back viscosity is the indication of gel constancy and degree of retrogradation (Liang and King, 2003; Niba et al., 2001). Retrogradation is a phenomenon occurred when amylose molecules rearrange themselves upon cooling of gel (Rodriguez-Sandoval et al., 2008). The hydrogen bonds among amylose molecules have the tendency to form double helical structure during cooling process (Denardin and Smith, 2009). Similarly, Chinma et al. (2010) stated that the high $\mathrm{SB}$ value is the indication of starch molecule disperse in hot paste and retrograde upon cooling. Final viscosity is the capability of starch granules to become retrograde upon cooling (Liang and King, 2003; Niba et al., 2001).

Similar to rest of pasting properties final viscosity of low amylose rice flour (Watni) also enhanced with the addition of high amylose rice flour (Lavange). Statistically, FV of blended samples are significantly $(p<0.05)$ different form each other. Data showed that LAHA (60:40) had higher FV mean value of (5520cP), while LAHA (20:80) had low FV mean value of $(3206 \mathrm{cP})$ Final viscosity increased from 1417cP (LAHA100:00) to 3206cp (LAHA 20:80). Same trend in final viscosity was also observed by Qazi et al. (2011), who concluded that the final viscosity of rice starch increased with addition of other starch sources and produced good quality noodles. Peak time, pasting temperature and pasting time has also increased with the increase of high amylose rice flour in the blend. Similar results are confirmed by Karim et al. (2008) who concluded that high granules rigidity and amylose increased the pasting properties of the rice flour. On the other hand, Noda et al. (2002) examined that starches having low content of amylose had low pasting properties.

Both peak time and pasting temperature (PT) of the blended flour samples of high and low amylose rice varieties were significantly $(p<0.05)$ varied from each other. High peak time of $(6.5 \mathrm{~min}$.) was observed in blended flour sample of (LAHA 80:20), while low peak time of (5.43min.) was observed for blend flour sample of (LAHA 20:80). The above results are also in agreement with the findings of Qazi et al. (2011), who showed similar range for the pasting parameters of rice flour. Both peak time and pasting temperature had significant role in final product, especially noodles (Hormdok and Noomhorm, 2007; Qazi et al., 2011).

\section{Conclusions and Recommendations}

In the initial stage of the research the physicochemical and functional properties of the flour of the selected rice varieties were studied and concluded that the color $\mathrm{L}^{*}$ of the flour of all the rice varieties were in the acceptable range for the noodles preparation. The moisture content of the flour of the selected varieties was less than $12 \%$ which is a safe limit for storage of flour and subsequently for noodles production. Flour of the selected rice varieties were also characterized from low to high amylose content. This is concluded that flour of Lavange had high amylose and Watni 
had low amylose content and were selected for noodles preparation and further study. The functional properties like WAI, WSI and SP of the high amylose flour were significantly different than that of low amylose rice flour. It is expected from the above conclusions that the high amylose rice flour would produce good quality noodles. In the second stage of the study different blends were made by mixing the high amylose rice flour to low amylose rice flour and were studied for amylose content and WAI, WSI and pasting profile. This is concluded that the amylose of the low amylose rice flour was increased to high level and the maximum amylose was obtained by LAHA 20:80 (22.74\%). The functional properties namely water solubility index, water absorption index and swelling power of the low amylose rice flour were lowered down by the addition of high amylose flour in the blends. The pasting properties were also modified by the addition of high amylose rice flour to low amylose rice flour.

\section{Novelty Statement}

No work has been reported so far regarding rice varieties grown in Khyber Pakhtunkhwa. High amylose rice variety was blended to modify various selected properties of low amylose rice variety. Further, this research will provide new market for underutilized rice variety such as Watni, etc.

\section{Author's Contribution}

Muhammad Ilyas: Collected the wheat varieties, performed the experiments, analyzed the data and wrote the manuscript.

Ihsan Mabood Qazi: Designed the research and edited the article.

Mohammad Ayub: Provided technical guidelines.

\section{Conflict of interest}

The authors have declared no conflict of interest.

\section{References}

AACC, 2013. Approved methods of the American Association of Cereal Chemists. $10^{\text {th }} \mathrm{ed}$. St. Paul, MN.

Adebowale, A.A., L.O. Sanmi and S.O. Awonorin. 2005. Effect of texture modifiers on the physicochemical and sensory properties of dried fufu. Food Sci. Technol. Int., 11(5): 373-382. https:// doi.org/10.1177/1082013205058531

Adeyeye, E.I. and P.A. Aye. 1998. The effect of sample preparation on proximate composition and the functional properties of African yam bean flours. Note 1 La Rivista Italiana DelleSostanze Grasse, LXXV-Maggio, pp. 253-261.

Adom, K.K., M.E. Sorrells and R.H. Liu. 2005. Phytochemicals and antioxidant activity of milled fractions of different wheat varieties. J. Agric. Food Chem., 53(6): 2297-2306. https:// doi.org/10.1021/jf048456d

Ahmad, I., I.M. Qazi and S. Jamal. 2015. Quality evaluation of noodles prepared from blending of broken rice and wheat flour. Starch/ Starke, 67(11): 905-912. https://doi.org/10.1002/ star.201500037

Ammar, M.S., A.E. Hegazy and S.H. Bedeir. 2009. Using of taro flour as partial substitute of wheat flour in bread making. World J. Dairy Food Sci., 4 (2): 94-99. https://citeseerx.ist.psu.edu/view$\mathrm{doc} / \mathrm{d}$ ? doi=10.1.1.503.2140andrep=rep1and type $=$ pdf

Aravind, N., M. Sissons, N. Egan and C. Fellows. 2012. Effect of insoluble dietary fiber addition on technological, sensory, and structural properties of durum wheat spaghetti. Food Chem., 132: 993-1002.

Azabagaoglum, O. and O. https://doi. org/10.1016/j.foodchem.2011.11.085 Gaytancioglu. 2009. Analyzing consumer preference to different rice varieties in Turkey. J. Agric. Trop. Sub., 42: 118-125.

Bhattacharya, K.R., 2009. Physicochemical basis of eating quality of rice. Cereal Foods World, 54(1): 18-28. https://doi.org/10.1094/CFW54-1-0018

Bhattacharya, M., S.Y. Zee and H. Corke. 1999. Physicochemical properties related to quality of rice noodles. J. Cereal Chem., 76: 861-867. https://doi.org/10.1094/ CCHEM.1999.76.6.861

Bilgicli, N., 2013. Some chemical and sensory properties of gluten-free noodle prepared with different legume, pseudo-cereal and cereal flour blends. J. Food Nutr. Res., 52(4): 251-255.

Cai, Y., C. Liu, W. Wang and K. Cai. 2011. Differences in physicochemical properties of kernels of two rice cultivars during grain formation. J. Sci. Food Agric., 91(11): 1977-1983. https:// doi.org/10.1002/jsfa.4404

Chandra, S. and Samsher. 2013. Assessment of 
functional properties of different flours. Afr. J. Agric. Res., 8(38): 4849-4853.

Chen, J.J., V.M.F. Lai and C.Y. Lii. 2003. Effects of compositional and granular properties of pasting viscosity of rice starch blends. J. Starch., 55: 203-212. https://doi.org/10.1002/ star.200390039

Chen, L., J.M. David, Z. Haihua, Z. Zipei, J. Zhengyu and T. Yaoqi. 2019. Impact of amylose content on structural changes and oil absorption of fried maize starches. Food Chem., 287: 28-37. https://doi.org/10.1016/j.foodchem.2019.02.083

Chiang, P.Y. and A.I. Yeh. 2002. Effect of soaking on wet-milling of rice. J. Cer. Sci., 35(1): 85-94. https://doi.org/10.1006/jcrs.2001.0419

Chinma, C.E.,J.O. Abu and J.A. Ojo. 2010. Chemical, functional and pasting properties of starches from brown and yellow tigernuts (Cyperusesculentus). Nigerian Food J., 28: 1-13. https:// doi.org/10.4314/nifoj.v28i2.62630

Chou, C., T. Yen and C. Li. 2014. Effects of different cooking methods and particle size on resistant starch content and degree of gelatinization of a high amylase rice cultivar in Taiwan. J. Food. Agric. Environ. 12(2): 610. https://doi. org/10.1234/4.2014.4321

David, O., E. Arthur, S.O. Kwadwo, E. Badu and P. Sakyi. 2015. Proximate composition and some functional properties of soft wheat flour. Int. J. Innov. Res. Sci. Eng. Technol., 4(2): 753-758.

Denardin, C.C. and L.P. deSilva. 2009. Starch granule structure and its regard with physicochemical properties. Ciencia Rural, 39: 945-954. https://doi.org/10.1590/S010384782009005000003

Dhital, S., Shrestha, A.K., J. Hasjim and M.J. Gidley. 2011. Physicochemical and structural properties of maize and potato starches as a function of granule size. J. Agric. Food Chem., 59(18): 10151-10161. https://doi.org/10.1021/ jf202293s

Eshun, G., 2012. Nutrient composition and functional properties of bean flours of three soya bean varieties from Ghana. Dept. Home Econ. Educ. F/o. Sci. Edu., University of Education, Winneba.

Fari, M.J.M., D. Rajapaksa and K.K.D.S. Ranaweera. 2011. Quality characteristics of noodles made from selected varieties of Sri Lankan rice with different physicochemical characteristics. J. Natl. Sci. Found. Sri Lanka., 39: 53-60. https://doi.org/10.4038/jnsfsr. v39i1.2923

Fresco, L., 2005. Rice is life. J. Food Compos. Anal., 18: 249-253. https://doi.org/10.1016/j. jfca.2004.09.006

Fu, B.X., 2008. Asian noodles: History, classification, raw materials, and processing. J. Food Res. Int., 41: 888-902. https://doi.org/10.1016/j. foodres.2007.11.007

Gular, S., H. Koksel and P.K.W. Nge. 2002. Effects of industrial pasta drying temperatures on starch properties and pasta quality. Food Res. Int., 35(5): 421-427. https://doi.org/10.1016/ S0963-9969(01)00136-3

Gulia, N., V. Dhaka and B.S. Khatkar. 2014. Instant noodles: Processing, quality, and nutritional aspects. Crit. Rev. Food Sci. Nutr., 54: 1386-1399. https://doi.org/10.1080/10408398 .2011 .638227

Gutierrez, A.D.R., S. Guilbert and B. Cuq. 2002. Description of microstructural changes in wheat flour and flour components during hydration by using environmental scanning electron microscopy. Lebensm-Wiss. U-Technol. 35: 730-740. https://doi.org/10.1006/fstl.2002.0932

Han, H.M., J.H. Cho and B.K. Koh. 2011. Processing properties of Korean rice varieties in relation to rice noodle quality. J. Food Sci. Biotech., 20: 1277-1282. https://doi.org/10.1007/ s10068-011-0176-5

Hatcher, D.W., M.J. Anderson, R.G. Desjardins, N.M. Edwards and J.E. Dexter. 2002. Effects of flour particle size and starch damage on processing and quality of white salted noodles. Cereal Chem., 79: 64-71. https://doi.org/10.1094/ CCHEM.2002.79.1.64

Heinio, R.L., M.W.J. Noort, K. Katina, S.A. Alam, N. Sozer, H.L. De Kock, M. Herslethe and K. Poutanen. 2016. Sensory characteristics of wholegrain and bran-rich cereal foods. A review. Trends Food Sci. Technol., 47: 25-38. https://doi.org/10.1016/j.tifs.2015.11.002

Heo, S., S.M. Lee, J.H. Shim, S.H. Yoo and S. Lee. 2013. Effect of dry and wetmilledrice flours on the quality attributes of gluten-free dough and noodles. J. Food Eng., 116: 213-217. https:// doi.org/10.1016/j.jfoodeng.2012.11.017

Hormdok, R. and A. Noomhorm. 2007. Hydrothermal treatments of rice starch forimprovement of rice starch noodle quality. LWT Food 
Sci. Technol., 40: 1723-1731. https://doi. org/10.1016/j.lwt.2006.12.017

Hoseney, R.C., 1994. Principles of cereal science and technology. $2^{\text {nd }}$ ed. Am. Assoc. Cereal Chem. Inc., St. Paul, Minnesota, USA.

Hossain, M.S., A.K. Singh and F.U. Zaman. 2009. Cooking and eating characteristics of some newly identified inter sub specific (indica/japonica) rice hybrids. J. Sci. Asia, 35: 320-325. https://doi.org/10.2306/scienceasia1513-1874.2009.35.320

Hu, G., S. Huang, S. Cao and Z. Ma. 2009. Effect of enrichment with hemicelluloses from rice bran on chemical and functional properties of bread. J. Food Chem., 115: 839-842. https:// doi.org/10.1016/j.foodchem.2008.12.092

Ishiguro, K., T. Noda, K. Kitahara and $\mathrm{O}$. Yamakawa. 2000. Retrogradation of Sweet potato Starch. Starch/Stärke. 52: 13-17. https://doi.org/10.1002/ (SICI)1521-379X(200001)52:1<13::AIDSTAR13>3.0.CO;2-E

Islam, M., Z.M. Shams-Ud-Din and M.M. Haque. 2011. Studies on the effect of brown rice and maize flour on the quality of Bread. J. Bangladesh Agric., 9(2): 297-304. https://doi. org/10.3329/jbau.v9i2.11044

Islam, M.Z., M.L.J. Tanyen, M.S.U. Din, M. Syduzzaman and M.M. Hoque. 2012. Physico-chemical and functionalproperties of brown rice (Oryza sativa) and wheat (Triticumaestivum) flour and quality of composite biscuit made thereof. J. Kri. Found. Agric., 10: 20-28. https://doi.org/10.3329/agric.v10i2.13135

Jane, J., Y.Y. Chen, L.F. Lee, A.E. McPherson, K.S. Wong and M. Radosavljevic, 1999. Effects of amylopectin branch chain length and amylose content on thegelatinization and pasting properties of starch. J. Cereal Chem., 76(5): 629-637. https://doi.org/10.1094/ CCHEM.1999.76.5.629

Jangchud, K., M. Boonthrapong and W. Prinyawiwatkul. 2004. Cooking properties of waxy and non-waxy rice. J. Cereal Sci., 47: 372-379. https://doi.org/10.1016/j.jcs.2007.05.018

Juliano, B.O., 1972. The rice caryopsis and its composition. In: Rice Chemistry and Technology, 1sted. Houston, D.F. (Ed). Am. Assoc. Cereal Chem., pp. 16-74.

Juliano, B.O., 1985. Criteria and test for rice grain. In: Juliano, B.O. Rice chemistry and technol- ogy. St. Paul, Minn. (USA) Am. Assoc. Cereal Chem. Inc., pp. 433-513.

Karim, A., M. Nadiha, F. Chen, Y. Phuah, Y. Chui and A. Fazilah. 2008. Pasting and retrogradation properties of alkali-treated sago (Metroxylon sagu) starch. Food Hydrocoll., 22(6): 1044-1053. https://doi.org/10.1016/j. foodhyd.2007.05.011

Kasemsuwan, T., T. Baileyb and J. Jane. 1998. Preparation of clear noodles with mixtures of tapioca and high-amylose starches. J. Carbohydr Poly., 3: 301-312. https://doi.org/10.1016/ S0144-8617(97)00256-7

Kassegn, H.H., 2018. Determination of proximate composition and bioactive compounds of the Abyssinian purple wheat. Cogent Food Agric., 4: 1421415. https://doi.org/10.1080/23311932 .2017 .1421415

Kaur, A., N. Singh, A.K. Ahlawat, S. Kaur, A.M. Singh, H. Chauhan and G.P. Singh. 2013. Diversity in grain, flour, dough and gluten properties amongst Indian wheat cultivars varying in high molecular weight subunits (HMWGS). Food Res. Int., 53: 63-72. https://doi. org/10.1016/j.foodres.2013.03.009

Kaur, M. and N. Singh. 2006. Relationships between selected properties of seed, flour, and starches from different chickpea cultivars. Int. J. Food Prop., 9: 597-608. https://doi. org/10.1080/10942910600853774

Kaushal, P.V. Kumar and H.K. Sharma. 2012. Comparative study of physico-chemical, functional, anti-nutritional and pasting properties of taro (Colocasiaesculenta), rice (Oryza sati$v a$ ), pegion pea (Cajanuscajan) flour and their blends. LWT-Food Sci. Technol., 48: 59-68.

Kinsella, J.E., 1976. Functional pr https://doi. org/10.1016/j.lwt.2012.02.028 operties of protein in food-A survey. Crit. Rev. J. Food Sci. Nutr., 5: 219.

Li, C.F. and B.S. Luh. 1980. Rice snack foods. In: Rice, production and utilization. B.S. Luh, ed. Avi: Westport, CT. Pages 690-711

Liang, X. and J.M. King. 2003. Pasting and crystalline property differences of commercial and isolated rice starch with added amino acids. J. Food Sci., 68(3): 832-838. https://doi. org/10.1111/j.1365-2621.2003.tb08251.x

Lin, Y.S., A.I. Yeh and C.Y. Lii. 2001. Correlation between starch retrogradation and water mobility as determined by differential scan- 
ning calorimetry (DSC) and nuclear magnetic resonance (NMR). J. Cereal Chem., 78(6): 647-653. https://doi.org/10.1094/ CCHEM.2001.78.6.647

Liu, W. and Q. Shen. 2007. Studies on the physicochemical properties of mung bean starch from sour liquid processing and centrifugation. J. Food Eng., 79(1): 358-363. https://doi. org/10.1016/j.jfoodeng.2006.01.065

Mares, D.J. and A.W. Campbell. 2001. Mapping components of flour and noodle colour in Australian wheat. Australian J. Agric. Res., 52(1112): 1297-1309. https://doi.org/10.1071/ AR01048

Masood, S.B., N. Muhammad, A. Saeed and S. Kamran. 2004. Effect of moisture and packaging on the shelf life of wheat flour. Int. J. Food Saf., 4: 1-6.

Murphy, P., 2000. Starch (chapter 3). In: G.O. Phillips and P.A. Williams (Eds.), Handbook of hydrocolloids Boca Raton, Florida: CRC Press. pp. 41- 65.

Naifu, W., G.G. Hou, M. Kweon and B. Lee. 2016. Effects of particle size on the properties of whole-grain soft wheat flour and its cracker baking performance. J. Cereal Sci., 69 (2016): 187-193. https://doi.org/10.1016/j. jcs.2016.03.010

Niba, L.L., M.M. Bokanga, F.L. Jackson, D.S. Schlimmme and B.W. Li. 2001. Physicochemical properties and starch granular characteristics of flour from various manihotesculenta (Cassava) genotypes. J. Food Sci., 67: 20-24. https:// doi.org/10.1111/j.1365-2621.2002.tb08709.x

Nishita, K.D. and M.M. Bean. 1982. Grinding methods: Their impact on rice flour properties. Cereal Chem., 59: 46-49.

Niu, M., G.G. Hou, L. Wang and Z.X. Chen. 2014. Effects of superfine grinding on the quality characteristics of whole-wheat flour and its raw noodle product. J. Cereal Sci., 60: 382-388. https://doi.org/10.1016/j.jcs.2014.05.007

Nnam, N.M., 2002. Evaluation of complementary foods based on maize, soybean, pawpaw and mango flour blends. Nig. J. Nutr. Sci., 22(23): 8-18.

Noda, T., T. Kimura, M. Otani, O. Ideta, T. Shimada, A. Saito and I. Suda. 2002. Physicochemical properties of amylase-free starch from transgenic sweet potato. Carbohydr. Polym., 49(3): 253-260.
8617(01)00343-5

Nura, M., M. Kharidah, B. Jamilah and K. Roselina. 2011. Textural properties of laksa noodle as affected by rice flour particle size. J. Int. Food Res., 18: 1309-1312.

Offia-Olua, B.I., 2014. Chemical, functional andpasting properties of wheat (Triticumspp)- walnut (Juglansregia) flour. Food Nutr. Sci., 5(16): 1591. https://doi.org/10.4236/ fns. 2014.516172

Okusu, H., S. Otsubo and J. Dexter. 2010. Wheat milling and flour quality analysis for noodles in Japan. Asian Noodles Sci. Technol. Process., pp. 57-73. https://doi. org/10.1002/9780470634370.ch3

Omeire, G.C., O.F. Umeji and N.E. Obasi. 2014. Acceptability of noodles produced from blends of wheat, acha and soybean composite flours. Nigerian Food J., 32(1): 31-37. https://doi. org/10.1016/S0189-7241(15)30093-X

Parada, J. and J.L. Santos. 2016. Interactions between starch, lipids, and proteins in foods: Microstructure control for glycemic response modulation. Crit. Rev. Food Sci. Nutr., 56(14): 2362-2369. https://doi.org/10.1080/10408398 .2013 .840260

Pedreschi, F., K. Kaack and K. Granby. 2006. Acrylamide content and color development in fried potato strips. Food Res. Int., 39(1): 40-46 https://doi.org/10.1016/j.foodres.2005.06.001.

Penfield, M.P. and A.D. Campbell. 1990. Starch. In: Experimental science. Academies press, San Diego, pp. 358-381. https://doi.org/10.1016/ B978-0-12-157920-3.50020-X

Qazi, I.M., S.K Rakshit, T.Tran, J. Ullah and Z.A Khan. 2014. Effect of blending selected tropical starches with rice flour on the cooking quality and texture of rice based noodles. Sarhad J. Agric., 30(2): 257-264.

Qazi,I.M., S.K. Rakshit and T.Tran.2011. Effect of physic- chemical properties of tropical starches and hydrocolloids on the gels texture and noodles water retention ability. J. Starch, 63: 558569. https://doi.org/10.1002/star.201000140

Qazi, I.M., S.K. Rakshit, T. Tran, J. Ullah and Z.A. Khan. 2014. Effect of blending selected tropical starches on pasting profile of rice flour. Sarhad J. Agric., 30(3): 357-368

Rodriguez-Sandoval, E., A. Fernandez-Quintero, A.P.S. Aldana and G. Cuvelier. 2008. Effect of processing conditions on the texture of 
reconstituted cassava dough. Braz. J. Chem. Eng., 25(4): 713-722. https://doi.org/10.1590/ S0104-66322008000400008

Rosniyana A., M.A. Hashifah and S.A.N. Shariffah. 2013. Nutritional content and storage stability of stabilized rice bran - MR 220. J. Trop. Agric. Food Sci., 37(2): 163-170.

Saeid, A., S. Hoque, U. Kumar, M. Das, N. Muhammad, M.M. Rahman and M. Ahmed.2015. Comparative studies on nutritional quality of commercial wheat flour in Bangladesh. Bangladesh J. Sci. Ind. Res., 50(3): 181-188. https:// doi.org/10.3329/bjsir.v50i3.25581

Sandhu, K. and M. Kaur. 2010. Studies on noodle quality of potato and rice starches and their blends in relation to their physicochemical, pasting and gel textural properties LWTFood Sci. Tech., 43(8): 1289-1293. https://doi. org/10.1016/j.lwt.2010.03.003

Sathe, S.K. and D.K. Salunkhe. 1981. Functional properties of the great northern bean proteins: emulsion, foaming, viscosity and gelation properties. J. Food Sci., 46: 71-81. https://doi. org/10.1111/j.1365-2621.1981.tb14533.x

Schirmer, M., A.Höchstötter, M. Jekle, E. Arendt and T. Becker. 2013. Physicochemicaland morphological characterization of different starches with variable amylose/amylopectin ratio. Food Hydrocolloids, 32(1): 52-63. https://doi. org/10.1016/j.foodhyd.2012.11.032

Schoch, T.J., 1964. Swelling power and solubility of granular starches. In: Whistler, R.I., Smith, R.J. and BeMiller, J.N., Editors, 1964. Methods in carbohydrate chemistry, New York: Academies press. pp. 106-108.

Siddiq, M., M. Nasir, R. Ravi, K.D. Dolan and M.S. Butt. 2009. Effect of defatted maize germ addition on the functional and textural properties of wheat flour. Int. J. Food Prop., 12: 860-870. https://doi.org/10.1080/10942910802103028

Singh, N., L. Kaur, N.S. Sodhi and K.S. Sekhon. 2005. Physicochemical, cooking and textural properties of milled rice from different Indian rice cultivars. Food Chem., 89:253-259. https:// doi.org/10.1016/j.foodchem.2004.02.032

Singh, N., N. Inouchi and K. Nishinari. 2006. Structural, thermal and viscoelastic characteristics of starches separated from normal, sugary and waxy maize. Food Hydrocolloids, 20(6): 923-935. https://doi.org/10.1016/j.foodhyd.2005.09.009
Singh, N., N. Isono, S. Srichuwong, T. Noda and K. Nishinari. 2008. Structural, thermal and visco-elastic properties of potato starches. Food Hydrocolloids, 22(6): 979-988. https://doi. org/10.1016/j.foodhyd.2007.05.010

Singh, U., 2001. Functional properties of grain legume flours. J. Food Sci. Tech., 38: 191-199.

Sofi, S.A., J. Singh, S.A. Mir and B.N. Dar. 2020. In vitro starch digestibility, cooking quality, rheology and sensory properties of gluten-free pregelatinized rice noodle enriched with germinated chickpea flour. LWT Food Sci. Tech., 133: 110090. https://doi.org/10.1016/j. lwt.2020.110090

Soh, H.N., M.J. Sissons and M.A. Turner. 2006. Effect of starch granule size distribution and elevated amylose content on durum dough rheology and spaghetti cooking quality. J. Cereal Chem., 83: 513-519. https://doi.org/10.1094/ CC-83-0513

Son, 2007. Nigerian industrial standard for pastas. Standard Organization of Nigeria.ICS: 664.68: 1-8.

Song, X., W. Zhu, Y. Pei, Z. Ai and J. Chen. 2013. Effects of wheat bran with different colors on the qualities of dry noodles. J. Cereal Sci., 58: 400407. https://doi.org/10.1016/j.jcs.2013.08.005

Sookdang, A., 1998. The modification of rice flours for rice noodle. MS thesis. Asian Institute of Technology: Pathumthani, Thailand.

Suraiya.J., I.M. Qazi and I. Ahmad. 2016. Comparative studies on flour proximate compositions and functional properties of selected $\mathrm{Pa}-$ kistani rice varieties B. Life Environ. Sci., 53 (1): 47-56.

Svihus, B., A.K. Uhlen and O.M. Harstad. 2005. Effect of starch granule structure, associated components and processing on nutritive value of cereal starch: A review. Anim. Feed Sci.Tech., 122(3): 303-320. https://doi.org/10.1016/j.anifeedsci.2005.02.025

Tan, H.Z., Z.G. Li. and B. Tan. 2009. Starch noodles: History, classification, materials, processing, structure, nutrition, quality evaluation and improving. J. Food Res. Int., 42: 551-576. https://doi.org/10.1016/j.foodres.2009.02.015

Techawipharat, J., M. Suphantharika and J.N. Bemiller. 2008. Effects of cellulose derivatives and carrageenans on the pasting, paste, and gel properties of rice starches. Carbohydr. Polym., 73(3): 417-426. https://doi.org/10.1016/j.carb- 
pol.2007.12.019

Tester, R.F. and W.R. Morrison. 1990. Swelling and gelatinization of cereal starches. Effects of amylopectin, amylose and lipids. Cereal Chem., 67: 551-557.

Tester, R.F., J. Karkalas and X. Qi. 2004. Starch composition, fine structure and architecture. J. Cereal Sci., 39(2): 151-165. https://doi. org/10.1016/j.jcs.2003.12.001

Tharise, N., E. Julianti and M. Nurminah. 2014. Evaluation of physico-chemical and unctional properties of composite flour from cassava, rice, potato, soybean and xanthan gum as alternative of wheat flour. Int. Food Res. J., 214: 16411649.

Thumrongchote, D., T. Suzuki, K. Laohasongkram and S. Chaiwanichsiri. 2012. Properties of Non glutinous Thai rice flour: Effect of rice variety.J. Phr. Biol. Chem. Sci., 3: 150.

Tsai. M.L., C.F. Li and C.Y. Lii. 1997. Effect of granular structures on the pasting behavior of starches. Carbohydrate., 74(6): 750-757.https:// doi.org/10.1094/CCHEM.1997.74.6.750

Tukomane, T., P. Leerapongnum and S. Shobasngob. 2007. Preparation and characterization of annealed enzymatically hydrolyzed tapioca starch and the utilization in tableting. StarchStarke, 59(1): 33-45. https://doi.org/10.1002/ star.200600524

Vandeputte, G.E., V. Derycke, J. Geeroms and J.A. Delcour. 2003. Rice starch. II. Structure aspect provides insight in to swelling and pasting properties. J. Cereal Sci., 38: 53-59. https://doi. org/10.1016/S0733-5210(02)00141-8

Vongsawasdi, P., M. Noppharat, N. Hiranyaprateep and V. Tirapong. 2009. Relationships between rheological properties of rice flour and quality of vermicelli. Asian. J. Food Agro-Indus., 2(2): 102-109.
Wadchararat, C., M. Thongngamand O. Naivikul. 2006. Characterization of pre-gelatinized and heat moisture treated rice flours. Kasetsart J. Natl. Sci., 40: 144-153.

Wang, S.J. and L. Copeland. 2012a. New insight into loss of swelling power and pasting profiles of acid-hydrolysed starch granules. StarchStarke, 64: 538-544. https://doi.org/10.1002/ star.201100186

Wang, S.J. and L. Copeland. 2012c. Nature of thermal transitions of native and acid hydrolysed pea starch: Does gelatinization really happen. Carbohydr. Polym., 7: 1507-1514. https://doi. org/10.1016/j.carbpol.2011.09.047

Yalcin, S. and A. Basman. 2008. Effects of gelatinisation level, gum and transglutaminase on the quality characteristics of rice noodle. Int. J. Food Sci. Technol., 43: 1637-1644. https://doi. org/10.1111/j.1365-2621.2007.01674.x

Ye, J.P., X.T. Hu, S.J. Luo, D.J. McClements, L. Liang and C.M. Liu. 2018. Effect of endogenous proteins and lipids on starch digestibility in rice flour. Food Res. Int., 106: 404-409. https://doi. org/10.1016/j.foodres.2018.01.008

Yoenyongbuddhagal, S. and A. Noomhorm. 2002. Effect of physicochemical properties of high-amylose Thai rice flours on vermicelli quality. Cer. Chem., 79(4): 481-416. https:// doi.org/10.1094/CCHEM.2002.79.4.481

Yuree, W., U. Dudsadee, P. Santhanee, P. Chureerat, R. Vilai and W. Nuanchawee. 2015. Quality assessment of noodles made from blends of rice flour and canna starch. Food Chem. 179: 8593.

Zhu, L., Q. Liu, Y. Sang, M. Gu and Y. Shi. 2010. Underlying reasons for waxy rice flours having different pasting properties. Food Chem., 120: 94-100. https://doi.org/10.1016/j.foodchem.2009.09.076 